\title{
IDENTIFYING THE ANTECEDENTS FOR RELATIONSHIP QUALITY MODEL AND ITS OUTCOMES FOR PRIORITY BANKING CUSTOMERS IN INDONESIA
}

\author{
Syafrizal $^{1}$, Nabsiah Abdul Wahid ${ }^{2 *}$, and Ishak Ismail ${ }^{3}$ \\ ${ }^{1}$ Economics Faculty, Kampus Unand Limau Manis, Andalas University, Indonesia \\ ${ }^{2}$ Graduate School of Business, Universiti Sains Malaysia, \\ 11800 USM Pulau Pinang, Malaysia \\ ${ }^{3}$ Faculty of Industrial Management, Universiti Malaysia Pahang, Gambang Campus, \\ 26300 Gambang, Pahang, Malaysia \\ *Corresponding author: nabsiah@usm.my
}

Published online: 30 June 2017

To cite this article: Syafrizal, Abdul Wahid, N., and Ismail, I. (2017). Identifying the antecedents for relationship quality model and its outcomes for priority banking customers in Indonesia. Asian Academy of Management Journal, 22(1), 131-150. https://doi.org/10.21315/aamj2017.22.1.6

To link to this article: https://doi.org/10.21315/aamj2017.22.1.6

\begin{abstract}
Indonesian banks have started to focus on finding the right relationship quality model to be applied to their day-to-day operation, particularly for their priority banking customers $(P B C)$ who contribute the most to their profitable growth. This study investigates firstly, whether positive emotional expression (PEE) acts as the antecedent to relationship quality (satisfaction and trust); and secondly, whether relationship quality (RQ) leads to wordof-mouth (WOM) and share-of-purchase (SOP) as its positive outcomes. Results from a survey carried out on 338 priority banking customers in Jakarta, Indonesia found that indeed PEE acts as the antecedent to $R Q$ while $R Q$ is positively linked to the WOM and SOP outcomes. These findings suggest that PEE, WOM, and SOP are variables that must be considered by Indonesian banks when they strategise to enhance the relationship quality of their priority banking customers.
\end{abstract}

Keywords: positive emotional expression, relationship quality, share-of-purchase, word-of-mouth, priority banking customers

(C) Asian Academy of Management and Penerbit Universiti Sains Malaysia, 2017. This work is licensed under the terms of the Creative Commons Attribution (CC BY) (http://creativecommons. org/licenses/by/4.0/). 


\section{INTRODUCTION}

Banks in Indonesia have identified priority banking customers (PBC) as the segment that contributes the most to their profits and growth. However, maintaining long term and quality relationship with these customers can be difficult as banks must not only identify their needs and wants but must also know how to make these happen. In this instance, it is really crucial for banks to be able to identify a relationship quality (RQ) model that can work for their clients. Establishing what RQ is supposed to be is difficult; as there is little consensus on its definition or on possible theory underpinning it in the literature (Fincham \& Beach, 2010). Although Jarvelin and Lehtinen's (1996) definition of RQ is one of the many accepted definitions today (it is defined as the extent to which the firm customer's relationship fulfills all of the customer's expectation, prediction, want or goal, and desire), which focused on firm-customer relationship, other definition has gone to the extent of referring to it as relationship happiness (Reynolds, Houlston, \& Coleman, 2014). While definition and underlying theory of RQ debates continue, the literature still acknowledges the need to build a better understanding of causal relations between RQ and various variables that can act as the antecedents and outcomes to/for RQ (Henning-Thurau, Gwinner, \& Gremler, 2002). To date, RQ is acknowledged as the predictor of relationship outcome (Al-Alak \& Alnawas, 2010; Castellanos-Verdugo \& Veerapermal, 2009; Chen, Shi, \& Dong, 2008), Thus, this study attempts to investigate whether positive emotional expression (PEE) acts as the antecedent to RQ (satisfaction and trust); and whether RQ leads to word-of-mouth (WOM) and share-of-purchase (SOP) as its positive outcomes for $\mathrm{PBC}$ in Indonesia. The findings could provide retail banks in Indonesia with a better understanding of the importance of variables that have affected RQ between them and their PBC.

\section{LITERATURE REVIEW}

The ability to control emotional display is the basic requirement of any service work as the focus lies in the service providers expressing only positive emotions (and hiding the negative ones) in their encounters with customers who can sometimes be difficult. Smiling, using a soothing tone of voice, positive body language, and good, friendly facial expression shown during provider-customer's interaction, in addition to technical skills display, can maximise the customer's satisfaction and simultaneously prevent any negative emotional display (boredom and frustration) from being revealed. Thus, PEE refers to only when positive emotions are displayed while negative ones are suppressed (Lam, Huang, \& Janssen, 2010), 
such that it can be summarised as a "service with a smile" (Grandey, 2008). Over the years, researchers have acknowledged many PEE attributes and investigated them (William \& DeSteno, 2008; Henning-Thurau et al., 2002; Lam et al., 2010; Pugh, 2001; Grandey, 2003; Rafaeli \& Sutton, 1987; Valdesolo \& Graham, 2014) in attempts to enhance firm-customer's long-term relationship. However, these studies are limited in number, particularly those that link the variables to RQ and other outcomes. Individuals with high positive emotion for instance, socially value such emotions, and thus, they tend to experience elevated life satisfaction and well-being compared to others (Bastian, Kuppens, De Roover, \& Diener, 2014).

Various definitions of PEE can be found in the literature. For example, Ashforth and Humphrey (1993, pp. 88-89) define it as "the act of expressing socially desired emotions during service transaction". Wharton and Erickson's (1993) definition concerns employee's behaviour, which according to Rafaeli and Sutton (1987) is displayed through a combination of facial expression, spoken words, tone of voice, smiling, and thanking. Friedman, Prince, Riggio, and Dimatteo (1980) further explain how an individual can express their emotions through verbal and non-verbal forms by combining facial expressions, voices, body movements, and gestures. An expressive person, for instance, uses non-verbal cues to motivate, captivate, move, and inspire other people, and this apparently has been found by Friedman et al. (1980) to be the characters of top Toyota salesman. According to Harker and Keltner (2001), individuals with positive emotion expressions and good eye contact are prone to create friendly, honest, and likeable person impression on others. Many studies find a positive link between service provider's PEE and customer's satisfaction (e.g., Oliver, 1997; Price \& Arnould, 1999; Pugh, 2001; Grandey, 2003; Grandey, Mattila, Fisk, \& Sideman, 2002). The affect as information model from social psychology for example, suggests that individuals rely on their mood as information cues to help them form an attitude, make judgment or evaluation, as well as form a productive social relationship (Schwartz \& Clore, 1988; Kring, 2010; Keltner, Oately, \& Jenkins, 2014) of the RQ from services they encounter like satisfaction, trust, and commitment.

In general, RQ is conceptualised in the literature as the quality of interaction between customers and service provider (Gummesson, 1987; Grandey, 2008). The interaction relates closely to a customer's belief that service providers have the ability and credibility in minimising the risk or uncertainty of a service that they purchase. In credence service like priority banking services, the risk and uncertainty of the service consumption will influence customers to not only feel satisfied but will further encourage them to develop trust with the service provider(s) in the relationship (Crosby, Evans, \& Cowles, 1990; Grandey, 2008). Thus, in this study, 
RQ is operationalised as a higher order construct with two components, namely, satisfaction and trust as seen in various research (Al-Alak \& Alnawas, 2010; Castellanos-Verdugo \& Veerapermal, 2009; Kim \& Cha, 2002).

Satisfaction can be considered as an act that can be either developed via one transaction or cumulative reactions. According to Oliver (1997), cumulative satisfaction differs from satisfaction with a transaction (or a single encounter) as the latter involves post evaluation (or affective reaction) of the transaction in question. Satisfaction is a cumulative act when it is evaluated based on customer's total experiences of product or service consumption (Anderson, Fornell, \& Lehmann, 1994). As for trust, the literature has slightly varied but generally similar in definitions over the years; for example as perceived confidence of one party on the reliability and integrity of the exchange partner (Morgan \& Hunt, 1994; Tung \& Carlson, 2013); perceived credibility and benevolence of other party (Ganesan, 1994; Geyskens, Steenkamp, \& Kumar, 1999); and belief that the words and promise of one party is reliable and as such will be fulfilled (Blau, 1964; Moorman, Deshpande, \& Zaltman, 1993; Schurr \& Ozanne, 1985). In other words, the development of trust is an interpersonal process rather than a personal characteristic of the trusted parties (Deshpande, Farley, \& Webster, 1993). It is important to note that both satisfaction and trust as a component of RQ are crucial in influencing a firm's decision to move away from the conventional business practice (i.e., transactional exchanges) to the more relevant and sustainable practice (i.e., relational exchanges) to help them build not only a strong but a quality relationship.

A customer's positive affect experience of a service encounter(s) often lead to positive evaluation (like satisfaction and trust) when the customer's expectations of service(s) they are provided with are confirmed in the relationship encounter (Giardini \& Frese, 2006). Previous research found that PEE can increase customer's satisfaction (Brotheridge \& Grandey, 2002; Wang, 2009; Redden, 2012; Pugh, 2001; Grandey, 2003; Grandey et al., 2002) as well as customer's trust (Ottati, Terkildsen, \& Hubbard, 1997; Krull \& Dill, 1998; Fischer, 2012; McAllister's, 1995).

The literature also reports positive links between RQ's components - satisfaction and trust and its outcomes. Customer's satisfaction for example has been found to lead to relationship outcomes like WOM, repeat purchase, frequent buy of product/ services, and buy more product variant/line (Wong, Hung, \& Chow, 2008; Dong, Shi, \& Chen, 2008; Crosby et al., 1990; Henning-Thurau et al., 2002; Chen et al., 2008). Over the years, the effect of customer's satisfaction on positive WOM is supported by many studies. For example, satisfied customers are found to convey their satisfying experiences to an average five others in comparison to nine for 
dissatisfied customers and their dissatisfying experience (Knauer, 1992). Recent studies also confirm that satisfaction has a significant effect on positive WOM (Satta, Parola, Penco, \& Persico, 2015; Su, Hsu, \& Swanson, 2014). Customer's satisfaction significant effect on SOP (repurchase intention) are frequently reported too (Bowden-Everson, Dagger, \& Elliott, 2013; Jang, Kim, \& Lee, 2013; Aldas-Manzano, Ruiz-Mafe, Sanz-Blas, \& Lassala- Navarré, 2011; Liu, Guo, \& Lee, 2011; Lin \& Ding, 2005; Caceres \& Paparoidamis, 2007; Shamdasani \& Balakrishnan, 2000; Rauyruen \& Miller, 2007).

As for trust, the literature has also acknowledged it as a determinant of a RQ's outcome (Berry, 1995; Gummeson, 1998) like WOM (Guenzi \& Georges, 2010; Chen et al., 2008), or SOP (Guenzi \& Georges, 2010; Chen et al., 2008). Baloglu, Zhong, and Tanford's (2014) study of a casino industry in Vegas for example found that trust has a significant effect on positive WOM. This is similar to Barreda, Bilgihan, and Kageyama's (2015) findings when customer's trust on social media is found to show significant effect on positive WOM as well as to Su et al. (2014) study that also uncover how customer's trust of the tourism destination significantly affects their positive WOM. It has been frequently reported that customer's trust has a significant effect on SOP (repurchase intention) and the examples include Guenzi and Georges (2010), Chen et al. (2008), Lin and Ding (2005), Shamdasani and Balakrishnan (2000), Azam (2015), Bowden-Everson et al. (2013), Butt and Aftab (2013), and Aldas-Manzano et al. (2011).

The reviews of the literature pertaining to these variables lead to the following hypotheses to be investigated:

H1: Service provider's PEE links significantly to RQ's satisfaction

H2: Service provider's PEE links significantly to RQ's trust

H3: RQ's satisfaction links significantly with SOP

H4: RQ's satisfaction links significantly with positive WOM

H5: RQ's trust links significantly with positive SOP

H6: RQ's trust links significantly with positive WOM

\section{METHOD}

The population of this study is PBC in Jakarta, Indonesia as the city is the capital of Indonesia as well as the business capital of the country. PBC from five top retail banks in Jakarta, Indonesia serves as samples for this study following judgmental 
sampling technique. The benefit of applying judgmental sampling is that it can provide the researcher with specific and relevant information as required for the study (Sekaran, 2006). PBC is judged suitable for participation in line with the recommendation made by the five banks' relationship managers who are available in each bank's priority outlets within a specified time period. Only those PBC who had finished their encounter in the outlets were approached and invited to participate in the study; and only those who were willing to participate took part in the survey. This resulted in a total of 338 usable questionnaires obtained from the PBC and further analysed with structural equation modelling technique using Smart PLS 2.0.

Items for all constructs were adapted from previous studies. The four items used for PEE construct were adapted from Tomiuk (2000):

1. When the relationship manager is happy, s/he shows his/her feelings towards me.

2. Whenever the relationship manager feels positive emotions, I can easily see exactly what $\mathrm{s} / \mathrm{he}$ is feeling.

3. The relationship manager laughs out loud when someone tells him/her jokes that they think are funny.

4. The body of the relationship manager reacts very strongly to positive emotional situations.

For the RQ constructs, two items for the satisfaction (STS) component were adopted from Al-Alak and Alnawas (2010):

1. I am satisfied with this bank's overall services.

2. I am pleased with relationship manager of this bank.

While another two STS components were taken from Smith and Barclay (1997):

1. I am satisfied with the relationship I have with this bank.

2. Comparatively, bank relationship here is quite good.

On the other hand, all five items for trust (TST) were adapted from Al-Alak and Alnawas (2010):

1. The relationship manager always keep his/her promises.

2. The relationship manager shows at all times that $\mathrm{s} / \mathrm{he}$ is reliable in service delivery. 
3. The relationship manager has been sincere in dealing with me.

4. The relationship manager is completely honest when dealing with me.

5. The relationship manager is always concerned in putting his/her customers' interests first.

For RQ's outcomes, the positive WOM was measured via two items (Al-Alak \& Alnawas, 2010):

1. I want to recommend this bank to others.

2. I want to tell other persons about good things of this bank.

Another one, i.e., "I will encourage friends and relatives to do business with this bank" was adapted from Zeithaml, Berry, and Parasuraman (1996).

On the other hand, SOP was measured via two items from Kim and Cha (2002):

1. I have increased my bank usage frequency.

2. I use other bank new products/services such as mutual fund, retail bond, bank assurance, etc.

One item, i.e., "I will do more business with this bank in the next few years" was taken from Zeithaml et al. (1996), and another one, i.e., "I will invest more funds through this bank in the future" was from Eisingerich and Bell (2008). All the constructs in this study were measured using a 7-points Likert scale.

\section{FINDINGS}

\section{Respondent's Profile}

The study found that the respondents' possessed the following characteristics (Table 1). Gender wise, the respondents were quite equal: $171(50.6 \%)$ of them were male population while the rest (167 people or $49.4 \%)$ were female. Of the 338 respondents, the majority were married (275 people or $81.4 \%$ ), within the age range of 25-44 years old (149 people or 44.1\%), held a first degree (S1) (182 people or 53.8\%) and with a job description as an entrepreneur (169 respondents or $50 \%)$. 
Table 1

Characteristics of respondents

\begin{tabular}{|c|c|c|c|c|c|}
\hline & Characteristics & & & Unit & $\%$ \\
\hline \multirow[t]{3}{*}{ I } & Gender & 1 & Male & 171 & 50.6 \\
\hline & & 2 & Female & 167 & 49.4 \\
\hline & & & Total & 338 & 100.0 \\
\hline \multirow[t]{5}{*}{ II } & Age & 1 & Under 25 years & 27 & 8.0 \\
\hline & & 2 & $25-44$ years & 149 & 44.1 \\
\hline & & 3 & 45-64 years & 146 & 43.2 \\
\hline & & 4 & 65 years and above & 16 & 4.7 \\
\hline & & & Total & 338 & 100.0 \\
\hline \multirow[t]{3}{*}{ III } & Marital status & 1 & Married & 275 & 81.4 \\
\hline & & 2 & Unmarried & 63 & 18.6 \\
\hline & & & Total & 338 & 100.0 \\
\hline \multirow[t]{7}{*}{ IV } & Job & 1 & Entrepreneur & 173 & 51.2 \\
\hline & & 2 & Professionals & 51 & 15.1 \\
\hline & & 3 & Private company employee & 56 & 16.6 \\
\hline & & 4 & State enterprise company's employee & 15 & 4.4 \\
\hline & & 5 & Lecturer/teacher & 16 & 4.7 \\
\hline & & 6 & $\begin{array}{l}\text { Others (retiree/pensioner, public servant, } \\
\text { police/army, housewife) }\end{array}$ & 27 & 8 \\
\hline & & & Total & 338 & 100.0 \\
\hline
\end{tabular}

\section{Measurement Model}

The measurement model for this study includes examining individual loading, validity, and reliability tests. Both Cronbach alpha and composite reliability were used to assess the reliability of measure for the constructs. The evaluation of construct validity consists of convergent and discriminant validity test. Following Hair, Ringle, and Sarstedt's (2011) suggestion, the values for Cronbach alpha and composite reliability value for this study were set at 0.7 or higher. As shown in Table 2 and Figure 1, both values for all constructs are above 0.7 (between 0.784 and 0.908 ; and 0.874 and 0.936 respectively), which indicate that adequate reliability has been achieved.

According to Hair et al. (2011), an item with the loading factor of less than 0.5 should be dropped from data analysis. However, in this study, the loading factor for all item constructs are found to be within an acceptable level: i.e., between 
0.789 (TST5) and 0.902 (SOP3). The detail of the loading factor for all items in this study is shown in Figure 1. Convergent validity was used to assess the validity of constructs. As Hair et al. (2011) suggested, the value of the AVE must be 0.5 and above to ensure that a latent variable has a good convergent validity. The results in Table 2 show that all latent variables in this study have the AVE above $0.5(0.656$ to 0.784 ), indicating that good convergent validity has been achieved for all the variables investigated.

Table 2

Correlation matrix

\begin{tabular}{lccccccccc}
\hline Variable & AVE & R.Square & $\alpha$ & CR & PEE & SOP & STS & TST & WOM \\
\hline PEE & 0.771 & 0.000 & 0.901 & 0.931 & $\mathbf{0 . 8 7 8}$ & & & & \\
SOP & 0.784 & 0.464 & 0.908 & 0.936 & 0.435 & $\mathbf{0 . 8 8 5}$ & & & \\
STS & 0.721 & 0.405 & 0.871 & 0.912 & 0.637 & 0.557 & $\mathbf{0 . 8 4 9}$ & & \\
TST & 0.656 & 0.114 & 0.869 & 0.905 & 0.337 & 0.579 & 0.391 & $\mathbf{0 . 8 1 0}$ & \\
WOM & 0.698 & 0.411 & 0.784 & 0.874 & 0.498 & 0.497 & 0.628 & 0.363 & $\mathbf{0 . 8 3 5}$ \\
\hline
\end{tabular}

Notes: $\alpha=$ Cronbach alpha; $\mathrm{CR}=$ composite reliability; $\mathrm{AVE}=$ average variance extracted; $\mathrm{PEE}=$ positive emotional expression; SOP = share-of-purchase; STS = satisfaction; TST = trust; WOM = word-of-mouth. Diagonal value (bold number) is square root of average variance extracted; the numbers below diagonal value are correlation.

Forner and Larcker's criterion was further carried out to check the discriminant validity of the constructs (Hair et al., 2011). This was done by comparing the square root result of AVE for each construct to the correlation of all the other constructs in the model (Table 2). The correlation for each construct that exceeded the square root of their AVE indicated that they may not have sufficient discriminant validity. As shown in Table 2, all of the square roots of AVE (shown in boldface in the main diagonal of both matrices) were found to be higher than the absolute correlation between constructs. This indicates that the construct discriminant validity in this study was fulfilled.

\section{Structural Model, Hypothesis Testing, and Results}

The analysis made in the study was closely constructed according to Hair et al.'s (2011) five steps procedure to test the relationship among latent variables in the structural model. The first step was the assessment of collinearity among independent variables by using tolerance and variance inflation factor (VIF) score. The second step was an assessment of the coefficient of determination $\left(\mathrm{R}^{2}\right)$. The third step was an examination of the effect size $\left(f^{2}\right)$. The fourth step was to test model predictive relevance $\left(\mathrm{q}^{2}\right)$. The final step was the assessment of the significance level of structural model path coefficient. 
Collinearity test was carried out using SPSS 20.0 to obtain the level of tolerance and VIF score to avoid any collinearity problem among independent variables in the study as advised by Hair et al. (2011). According to Kline (1998), a collinearity problem in research model exists when the analysis result shows a score of tolerance below 0.1 and VIF score higher than 10.00 . The collinearity check on this study's data found a level of tolerance at 0.851 which was more than 0.1 and the value of VIF at 1.176 which was lower than 10.00 . Since the level of tolerance was higher than 0.2 and VIF score was lower than 10.00 , the results indicated that there was no collinearity issue on the data used in this study.

The second step was intended to assess the coefficient of determination $\left(\mathrm{R}^{2}\right)$. The rule of thumb states that $\mathrm{R}^{2}$ value $0.75,0.5$, and 0.25 indicate that the predictive accuracy of the research model is high, medium, and low consecutively (Hair et al., 2011; Henseler, Ringle, \& Sinkovics, 2009). This study found that $\mathrm{R}^{2}$ for WOM and SOP were at 0.411 and 0.464 respectively. Since the scores of $\mathrm{R}^{2}$ for WOM and SOP were close to 0.5 , these indicated that the predictive accuracy of the research model in this study was moderate.

Both Hair et al. (2011) and Cohen (1998) state that the effect size $\left(f^{2}\right)$ of an exogenous variable with scores at $0.02,0.15$, and 0.35 should be concluded to be small, medium, and large consecutively. For this study, the score of $f^{2}$ for STS and TST to predict WOM were found to be 0.470 and 0.029 respectively. These results indicated that while the $f^{2}$ of STS to WOM was large, the $f^{2}$ of TST to WOM was considered small. Further analysis found that the score of $f^{2}$ for STS and TST to predict SOP were 0.241 and 0.222 respectively, indicating that the $f^{2}$ of STS and TST to SOP was medium.

The fourth step, namely the predictive relevance $\left(\mathrm{q}^{2}\right)$ of the study's model was assessed by using the blinfolding result. It was found that the value of the $\mathrm{q}^{2}$ for this research model was 0.15 . According to Hair et al. (2011), the score of $\mathrm{q}^{2}$ at $0.02,0.15$, and 0.35 are to be subsequently considered as small, medium, and large. Following Hair et al.'s (2011) advice, the $\mathrm{q}^{2}$ of this research model was only moderate since the score of $\mathrm{q}^{2}$ for this research was found to be at 0.15 .

The last step requires the significance level of structural model path coefficient to be assessed. Thus, the significance level of the relationship among latent variables in this research model was assessed using t-value. The PLS-algorithm analysis was performed to get the beta value (path value coefficient) for the structural model (latent variable relationship). Bootstrapping analysis was then carried out to examine the significance level of the relationship among latent variables in the structural model. Table 3 illustrate the summarised results of hypotheses tested in the study. 
Table 3

Summary of hypothesis and significance of structural path coefficient

\begin{tabular}{cccccc}
\hline \multicolumn{5}{c}{ Research Hypothesis } \\
\hline No & Hypothesis & \multicolumn{1}{c}{ Path } & Path coefficient $(\beta)$ & t-value & Supported \\
\hline 1 & H1 & PEE $\rightarrow$ STS & 0.637 & 12.564 & Yes \\
2 & H2 & PEE $\rightarrow$ TST & 0.337 & 5.240 & Yes \\
5 & H3 & STS $\rightarrow$ SOP & 0.390 & 6.334 & Yes \\
6 & H4 & STS $\rightarrow$ WOM & 0.574 & 10.315 & Yes \\
7 & H5 & TST $\rightarrow$ SOP & 0.426 & 7.384 & Yes \\
8 & H6 & TST $\rightarrow$ WOM & 0.139 & 2.298 & Yes \\
\hline
\end{tabular}

The results in Table 2 show that $\mathrm{R}^{2}$ value of satisfaction (STS) and trust (TST) are at 0.405 and 0.114 respectively. In other words, as much as $40.5 \%$ variance in satisfaction and $11.4 \%$ variance in trust are explained by PEE (see Figure 1). Further examinations on beta value for PEE-STS finds $\beta=0.637(\mathrm{t}=12.564$; $p<0.001$; see Table 3 ) and on beta value for PEE-TST finds $\beta=0.337(\mathrm{t}=5.240$; $p<0.01$; see Table 3 ). From these $\mathrm{R}^{2}$ and $\beta$ values, the study concludes that both H1 (PEE links positively to RQ's satisfaction) and H2 (PEE links positively to RQ's trust) are supported.

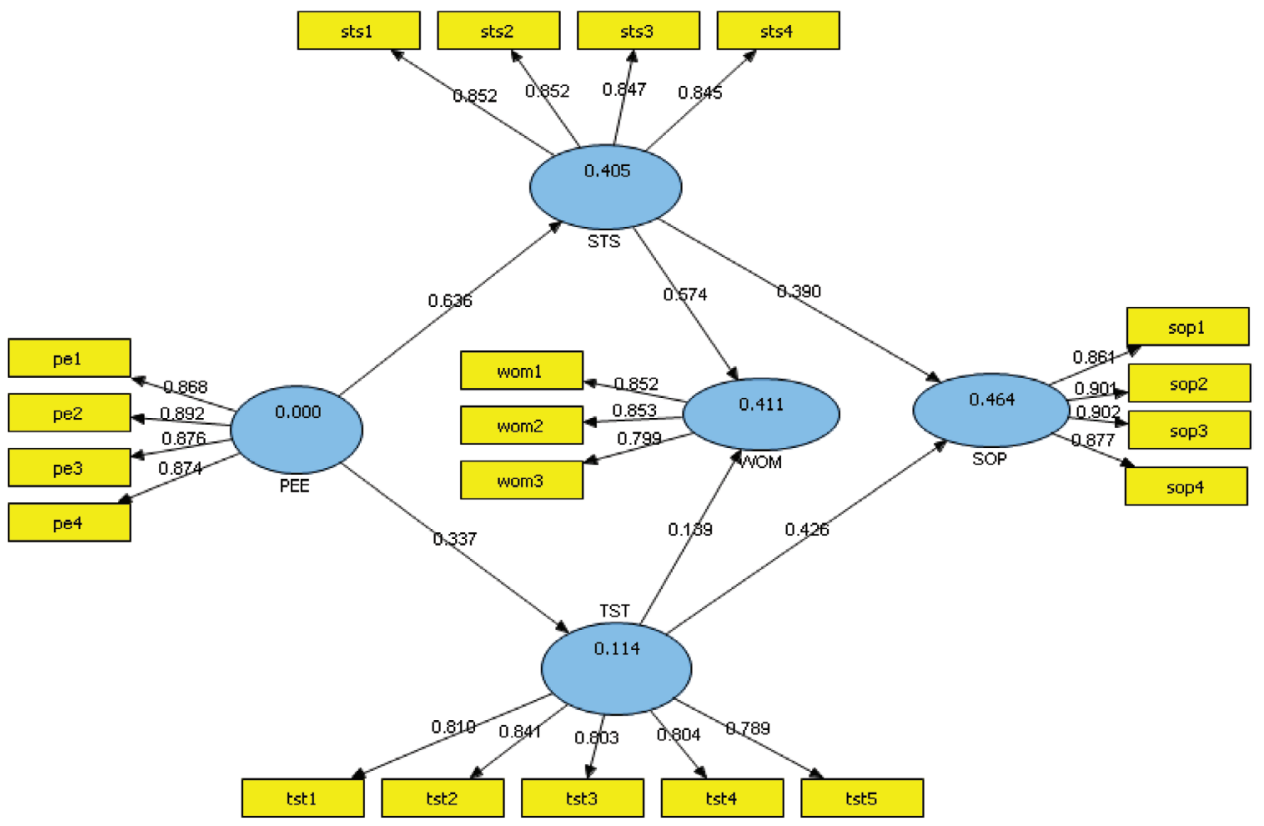

Figure 1. Research model 
As for H3, H4, H5, and H6, Figure 1 and Table 2 show that $\mathrm{R}^{2}$ value of SOP and WOM are at 0.464 and 0.411 respectively. This means that $46.4 \%$ variance in the SOP and $41.1 \%$ variance in positive WOM are explained by RQ's satisfaction and trust. Further investigation on the beta value for (STS-SOP) finds that $\beta=0.390$ $(\mathrm{t}=6.334 ; p<0.01$; see Table 3$)$; beta value for (STS-WOM) finds that $\beta=0.574$ $(\mathrm{t}=10.315 ; p<0.001$; see Table 3$)$; beta value for (TST-SOP) found that $\beta=426$ $(\mathrm{t}=7.384 ; p<0.001$; see Table 3$)$; beta value for (TST-WOM) found that $\beta=0.139$ $(\mathrm{t}=2.298 ; p<0.001$; see Table 3$)$. These results indicate that all hypotheses $\mathrm{H} 3$, $\mathrm{H} 4, \mathrm{H} 5$, and $\mathrm{H} 6$ are supported.

\section{DISCUSSION AND CONCLUSION}

The results for all hypotheses tested lead to several conclusions. First, the positive emotional expression has a significant effect on RQ in terms of satisfaction and trust. Second, both RQ components, i.e., satisfaction and trust, have significant influence over a SOP and positive WOM. These findings and conclusions are found to be in line with previous studies. For example, the positive link found between PEE and RQ's satisfaction is in line with various studies carried out over the years, for instance, by Pugh (2001), Grandey (2003), Brotheridge and Grandey (2002), Wang (2009), and Redden (2012). Similarly, the positive link between PEE and RQ's trust is in line with studies by Fischer (2012) and McAllister (1995). The positive link between RQ's satisfaction and trust with WOM are also in line with previous studies like Henning-Thurau et al. (2002), Chen et al. (2008), Satta et al. (2015), and $\mathrm{Su}$ et al. (2014) for satisfaction; while Guenzi and Georges (2010), Chen et al. (2008), Baloglu et al. (2014), and Su et al. (2014) for trust. In addition, the positive link between RQ's satisfaction and trust with SOP are also similar to Lin and Ding (2005), Caceres and Paparoidamis (2007), Shamdasani and Balakrishnan (2000), Rauyruen and Miller (2007), Chen et al. (2008), Lonial and Raju (2015), and Kim, Lee, and Suh (2015) for satisfaction; while Guenzi and Georges (2010), Chen et al. (2008), Lin and Ding (2005), Shamdasani and Balakrishnan (2000), Azam (2015), Bowden-Everson et al. (2013), Butt and Aftab (2013) and Aldas-Manzano et al. (2011) for trust.

These findings indicate the importance of PEE, WOM, and SOP to be considered as part of the banks' strategies to enhance their RQ with their priority banking customers. PBC, as a segment that contributes considerably to any bank's profits and growth, has every justification to be served and treated with care. Banks in Indonesia are currently appointing relationship managers to manage this important relationship. The study's findings have shown how PEE can lead to positive customer satisfaction as well as trust. This means that bank employees, particularly the 
relationship manager, must continue to display only positive emotions during and in each of their interaction with PBC at all times. Banks are clearly characterised by credence service. Offering priority banking services only extend this credence further, coupled with a formidable interaction by the relationship managers during each encounter with the PBC. If the managers can keep their calm when dealing with PEE and behave as per expected by the PBC, banks can be assured that these will produce a positive experience for these customers, improve interaction, and induces customer's satisfaction and trust.

In this study, it is also found that customer's satisfaction and trust in the RQ both lead to positive WOM and SOP. These findings indicate that satisfied customers will have the intention to buy more of the bank's product and services, convey positive things about the bank and voluntarily promote the banks to others while dissatisfied one will express negative things as the marketing theory assumed. Similarly for trust, customer's trust in the RQ implies that the customers, i.e., the PBC, believe in the service provider's (in this case, the relationship manager) credibility and reliability to deliver products/services as promised. In addition, trust is also related to the customer's belief that the bank as the service provider has placed an interest in the customer's welfare and benevolence. Hence, when the customers trust the bank, the tendency is for them to buy more of the bank's products and services, and recommend the bank to their friends, relatives, and other people. This is important as positive information from existing customers particularly priority customers is more effective to entice potential customers to the banks. Interestingly, previous literature in priority/private banking is found to mention that referral from existing customers is an important source of new customers (Maude, 2006; McCarte, 2006; Wyman, 2008). In other words, satisfied customers and customers with trust will produce referral effect which in turn can establish a new relationship with the company apart from linking repeat purchase for themselves. Thus, it is safe to conclude that satisfied customers and customers with trust are very important for the bank's growth through a SOP by their existing customers and potential customers. Banks really need positive WOM to enhance their growth and increase survivability in the marketplace. Positive WOM (referral effect) in priority banking services is one of the important means to establish a new relationship with potential customers, thus creating another business opportunity to generate growth for the banks. For banks that cater important segments like PBC, the findings imply how crucial it is for them to improve the interaction quality of their employees when servicing customers at all times. As it is imperative for the service employees (e.g., relationship managers) to express positive emotions and avoid negative emotions in every service encounter, continuous training on relationship quality and services, and evaluating and monitoring that relationship quality through key performance indicators may be helpful to maintain or refining 
the relationship between bank's employees as service providers and $\mathrm{PBC}$ so that the relationship will be astoundingly appreciated and valued.

\section{ACKNOWLEDGEMENT}

The authors would like to acknowledge the research grant provided by the Ministry of Education Malaysia under the Long Term Research Grant Scheme (LRGS) No. 203/PKT/6726002 and those who have took part and provided us with information for this study.

\section{REFERENCES}

Al-Alak, B.A.M., \& Alnawas, I.A.M. (2010). Evaluating the effect of marketing activities on relationship quality in the banking sector: The case of private commercial banks in Jordan. International Journal of Marketing Studies, 2(1). https://doi.org/10.5539/ijms.v2n1p78

Aldas-Manzano, J., Ruiz-Mafe, C., Sanz-Blas, S., \& Lassala-Navarré, C. (2011). Internet banking loyalty: Evaluating the role of trust, satisfaction, perceived risk and frequency of use. The Service Industries Journal, 31(7), 1165-1190. https://doi. org/10.1080/02642060903433997

Anderson, E.W., Fornell, C., \& Lehmann, D.R. (1994). Customer satisfaction, market share and profitability: Findings from Sweden. Journal of Marketing, 58, 53-66. https://doi.org/10.2307/1252310

Ashforth, B.E., \& Humphrey, R.H. (1993). Emotional labor in service roles: The influence of identity. Academy of Management Review, 18, 88-115. https://doi. org/10.2307/258824 \& https://doi.org/10.5465/AMR.1993.3997508

Azam, A. (2015). Investigation of psychological dimensions of trust on e-loyalty: A case of Saudi Arabia consumers. Journal of Islamic Marketing, 6(2), 224-249. https://doi.org/10.1108/JIMA-12-2013-0083

Baloglu, S., Zhong, Y.Y., \& Tanford, S. (2014). Casino loyalty: The influence of loyalty program, switching costs and trust. Journal of Hospitality and Tourism Research, 20(10), 1-23. https://doi.org/10.1177/1096348014550922

Barreda, A.A., Bilgihan, A., \& Kageyama, Y. (2015). The role of trust in creating positive word-of-mouth and behavioral intentions: The case of online social networks. Journal of Relationship Marketing, 14(1), 16-36. https://doi.org/10.1080/15332 667.2015.1006002

Bastian, B., Kuppens, P., De Roover, K., \& Diener, E. (2014). Is valuing positive emotion associated with life satisfaction? Emotion, 14(4), 639-645. https://doi. org $/ 10.1037 / \mathrm{a} 0036466$ 
Berry, L.L. (1995). Relationship marketing of service: Growing interest, emerging perspectives. Journal of the Academy of Marketing Science, 23(4), 236-245. https://doi.org/10.1177/009207039502300402

Blau, P. (1964). Exchange and power in social life. New York: John Wiley \& Sons, Inc.

Bowden-Everson, J.L.H., Dagger, T.S., \& Elliott, G. (2013). Engaging customers for loyalty in the restaurant industry: The role of satisfaction, trust, and delight. Journal of Foodservice Business Research, 16(1), 52-75. https://doi.org/10.1080 $/ 15378020.2013 .761025$

Brotheridge, C.M., \& Grandey, A.A. (2002). Emotional labor and burnout: Comparing two erspectives of "people work". Journal of Vocational Behavior, 60(1), 17-39. https://doi.org/10.1006/jvbe.2001.1815

Butt, M.M., \& Aftab, M. (2013). Incorporating attitude towards halal banking in an integrated service quality, satisfaction, trust and loyalty model in online Islamic banking context. International Journal of Bank Marketing, 31(1), 6-23. https:// doi.org/10.1108/02652321311292029

Caceres, R.C., \& Paparoidamis, N.G. (2007). Service quality, relationship satisfaction, trust, commitment and business-to-business loyalty. European Journal of Marketing, 41(7/8), 836-867. https://doi.org/10.1108/03090560710752429

Castellanos-Verdugo, M., \& Veerapermal, N. (2009). The employee-customer relationship quality: Antecedents and consequences in the hotel industry. International Journal of Contemporary Hospitality Management, 21(3), 251-274. https://doi. org/10.1108/09596110910948288

Chen, Z.X., Shi, Y., \& Dong, D-H. (2008). An empirical study of relationship quality in a service setting: A Chinese case. Marketing Intelligence and Planning, 26(1), 11-25. https://doi.org/10.1108/02634500810847129

Chow, W-K., Wong, Y.H., \& Hung, H. (2007). Mediating effects of relationship quality on customer relationships: An empirical study in Hong Kong. Marketing Intelligence and Planning, 25(6), 581-596. https://doi.org/10.1108/02634500710819950

Cohen, J. (1988). Statistical power analysis for the behavioral sciences. Mahwah, NJ: Lawrence Erlbaum. https://doi.org/10.1002/bs.3830330104

Crosby, L.A., Evans, K.R., \& Cowles, D. (1990). Relationship quality in service selling: An interpersonal influence perspective. Journal of Marketing, 54(July), 68-81. https://doi.org/10.2307/1251817

Deshpande, R., Farley, J.U., \& Webster, F.E. (1993). Corporate culture, customer orientation, and innovativeness in Japanese firms: A quadrad analysis. Journal of Marketing, 57(January), 23-27. https://doi.org/10.2307/1252055

Dong, D-H., Shi, Y., \& Chen, Z.X. (2008). An empirical study of relationship quality in a service setting: A Chinese case. Marketing Intelligence and Planning, 26(1), 11-25. https://doi.org/10.1108/02634500810847129

Dorsch, M.J., Swanson, S.R., \& Kelley, S.W. (1998). The role of relationship quality in the stratification of vendors as perceived by customers. Journal of the Academy of Marketing Science, 26(2), 128-42. https://doi.org/10.1177/0092070398262004

Eisingerich, A.B., \& Bell, S.J. (2008). Maintaining customer relationships in high credence services. Journal of Services Marketing, 21(4), 253-262. https://doi. org/10.1108/08876040710758559 
Fincham, F., \& Beach, S. (2010). Marriage in the new millennium: A decade in review. Journal of Marriage and Family, 72, 630-649. https://doi.org/10.1111/j.17413737.2010.00722.x

Fischer, M. (2012). The role of positive emotions in the creation of positively deviant business-to-business services. Advances in the Human Side of Service Engineering, 179-192.

Friedman, H.S., Prince, L.M., Riggio, R.E. \& Dimatteo, M.R. (1980). Understanding and assessing nonverbal expressiveness: The affective communication test. Journal of Personality and Social Psychology, 39, 333-351. https://doi.org/10.1037/00223514.39.2.333

Ganesan, S. (1994). Determinants of long-term orientation in buyer-seller relationships. Journal of Marketing, 58(April), 1-19. https://doi.org/10.2307/1252265

Geyskens, I., Steenkamp, Jan-Benedict E.M., \& Kumar, N. (1999). A meta-analysis of satisfaction in marketing channel relationships. Journal of Marketing Research, 36, 223-238. https://doi.org/10.2307/3152095

Giardini, A., \& Frese, M. (2006). Reducing the negative effects of emotion work in service occupations: Emotional competence as a psychological resource. Journal of Occupational Health Psychology, 11, 63-75. https://doi.org/10.1037/10768998.11.1.63

Grandey, A.A. (2003). When the 'Show Must Go On': Surface acting and deep acting as determinants of emotional exhaustion and peer-rated service delivery. Academy of Management Journal, 46, 86-96. https://doi.org/10.2307/30040678

Grandey, A.A. (2008). Emotions at work: A review and research agenda. In C. Cooper \& J. Barling (Eds.), Handbook of organizational behavior (pp. 235-261). London: Sage. https://doi.org/10.4135/9781849200448.n14

Grandey, A.A., Mattila, A.S., Fisk, G.M., \& Sideman, L.A. (2002). Is that smile for real? Authenticity of positive displays during service encounters. Denver, CO: Academy of Management.

Guenzi P. \& Georges, L. (2010). Interpersonal trust in commercial relationship. European Journal of Marketing, 44(1/2), 114-138. https://doi. org/10.1108/03090561011008637

Gummesson, E. (1987). The new marketing-developing long-term interactive relationships. Long Range Planning, 20(4), 10-20. https://doi.org/10.1016/00246301(87)90151-8

Gummesson, E. (1998). Productivity, quality and relationship marketing in service operation. International Journal of Contemporary Hospitality Management, 10(1), 4-15. https://doi.org/10.1108/09596119810199282

Hair, J.F., Ringle, C.M., \& Sarstedt, M. (2011). PLS-SEM: Indeed a silver bullet. Journal of Marketing Theory and Practice, 19(2), 139-151. https://doi.org/10.2753/ MTP1069-6679190202

Harker, L.A., \& Keltner, D. (2001). Expression of positive emotion in womens' college yearbook pictures and their relationship to personality and life outcomes across adulthood. Journal of Personality and Social Psychology, 80(1), 112-124. https:// doi.org/10.1037/0022-3514.80.1.112 
Henning-Thurau, T., Gwinner, K.P., \& Gremler, D.D. (2002). A integration of relational benefits and relationship quality. Journal of Service Research, 4(3), 230-247. https://doi.org/10.1177/1094670502004003006

Henseler, J., Ringle, C.M., \& Sinkovics, R.R. (2009). The use of partial least squares path modeling in international marketing. In R.R. Sinkovics, \& P.N. Ghauri (Eds.), New challenges to international marketing (Advances in International Marketing, Volume 20) (pp. 277-319). United Kingdom: Emerald Group Publishing Limited.

Jang, J.H., Kim, S.W., \& Lee, Y.S. (2013). The effect of relationship benefit on relationship quality and store loyalty from convergence environments-NPS analysis and moderating effects. Electron Commerce Res, 13, 291-315. https://doi.org/10.1007/ s10660-013-9117-0

Jarvelin, A., \& Lehtinen, U. (1996). Relationship quality in business-to-business service context. In B. Brown, S.W. Edvardsson, R. Johnston, \& E.E. Scheuing (Eds.), QUIS 5 advancing service quality: A global perspective. Leamington Spa: Warwick Printing Company.

Keltner, D., Oately, K., \& Jenkins, J.M. (2014). Understanding emotions. Hobokens, NJ: Wiley.

Kim, J.W., Lee, F., \& Suh, Y.G. (2015). Satisfaction and loyalty from shopping mall experience and brand personality. Services Marketing Quarterly, 36(1), 62-76. https://doi.org/10.1080/15332969.2015.976523

Kim W.G. \& Cha, Y. (2002). Antecedents and consequences of relationship quality in hotel industry. Hospitality Management, 21, 321-338. https://doi.org/10.1016/S02784319(02)00011-7

Kline, R.B. (1998). Principles and practice of structural equation modelling. New York: The Guilford Press.

Knauer. V. (1992). Increasing of customer satisfaction. USA: United State Office of Consumer Affair, Pueblo, CO.

Kring, A.M. (2010). The future of emotion research in the study of psychopathology. Emotion Review, 2, 225-228. https://doi.org/10.1177/1754073910361986

Krull, D.S., \& Dill, J.C. (1998). Do smiles elicit more inferences than do frowns? The effect of emotional valence on a production of spontaneous inferences.

Personality and Social Psychology Bulletin, 24(3), 289-300. https://doi. org/10.1177/0146167298243006

Kumar, N., Scheer, L.K., \& Steenkamp, J-B.E.M. (1995). The effects of supplier fairness on vulnerable resellers. Journal of Marketing, 32, 54-65. https://doi. org $/ 10.2307 / 3152110$

Lam, C.K., Huang, X., \& Janssen, O. (2010). Contextualizing emotional exhaustion and positive emotional display: The signaling effects of supervisors' emotional exhaustion and service climate. Journal of Applied Psychology, 35(2), 368-376. https://doi.org/10.1037/a0017869 
Lin, C-P., \& Ding C.G. (2005). Opening the black box: Assessing the mediating mechanism of relationship quality and the moderating effects of prior experience in ISP service. International Journal of Service Industry Management, 16(1), 55-80. https://doi.org/10.1108/09564230510587159

Liu, C-T., Guo, Y.M., \& Lee, C-H. (2011). The effects of relationship quality and switching barriers on customer loyalty. International Journal of Information Management, 31, 71-79. https://doi.org/10.1016/j.ijinfomgt.2010.05.008

Lonial, S., \& Raju, P.S. (2015). Impact of service attributes on customer satisfaction and loyalty in a healthcare context. Leadership in Health Services, 28(2), 149-166. https://doi.org/10.1108/LHS-12-2013-0045

Maude, D. (2006). Global private banking and wealth management. West Sussex, England: John Wiley \& Sons. https://doi.org/10.1002/9781118673386

McAllister, D.J. (1995). Affect-and cognition based trust as foundations for international cooperation in organizations. Academy of Management Journal, 38(1), 24-59. https://doi.org/10.2307/256727

McCarte, S. (2006). Private banking and wealth management. Scotland: Chartered Institute of Bankers.

Morgan, R.M., \& Hunt, S.D. (1994). The commitment-trust theory of relationship marketing. Journal of Marketing, 58(July), 20-38. https://doi.org/10.2307/1252308

Moorman, C., Deshpande, R., \& Zaltman, G. (1993). Factors affecting trust in market research relationships. Journal of Marketing, 57(January), 81-101. https://doi. org/10.2307/1252059

Nunnally, J. (1978). Psychometric theory. New York: McGraw-Hill.

Oliver, R.L. (1997). Satisfaction: A behavioral perspective on the consumer. New York: McGraw-Hill.

Ottati, V., Terkildsen, N., \& Hubbard, C. (1997). Happy faces elicit heuristic processing in a televised impression formation task: A cognitive tuning account. Personality and Social Psychology Bulletin, 23(11), 1144-1156. https://doi. org/10.1177/01461672972311003

Price, L., \& Arnould, E. (1999). Commercial friendships: Service provider-client relationship in context. Journal of Marketing, 63(4), 38-56. https://doi.org/10.2307/1251973

Pugh, S.D. (2001). Service with a smile: Emotional contagion in the service encounter. AcademyofManagementJournal,44,1018-1027.https://doi.org/10.2307/3069445

Rafaeli, A., \& Sutton, R.I. (1987). Expression of emotion as part of the work role. The Academy of Management Review, 12, 23-37. https://doi.org/10.2307/257991 \& https://doi.org/10.5465/AMR.1987.4306444

Rauyruen, P., \&. Miller, K.E. (2007). Relationship quality as a predictor of B2B customer loyalty. Journal of Business Research, 60, 21-31. https://doi.org/10.1016/j. jbusres.2005.11.006

Redden, S.M. (2012). How lines organize compulsory interaction, emotion management, and "emotional taxes": The implications of passenger emotion and expression in airport security lines. Management Communication Quarterly, 27(1), 121-149. https://doi.org/10.1177/0893318912458213 
Reynolds, J., Houlston, C., \& Coleman, L. (2014). OnePlusOne understanding relationship quality. Retrieved 24 May 2016 from http://www.oneplusone.org.uk/wp-content/ uploads/2014/02/UnderstandingRelationship-Quality-by-Jenny-Reynolds-DrCatherine-Houlston-and-Dr-Lester-Coleman.pdf.

Satta, G., Parola, F., Penco, L., \& Persico, L. (2015). Word-of-mouth and satisfaction in cruise port destinations. Tourism Geographies: An International Journal of Tourism Space, Place and Environment, 17(1), 54-75. https://doi.org/10.1080/14 616688.2014.938689

Schurr, P.H., \& Ozanne, J.L. (1985). Influences on exchange processes: Buyers' preconceptions of a seller's trustworthiness and bargaining toughness. Journal of Consumer Research, 11(March), 939-953. https://doi.org/10.1086/209028

Schwartz, N., \& Clore, G.L. (1988). How do I feel about it? The informative function of affective states. In K. Fiedler \& J.P. Forgas (Eds.), Affect, cognition, and social behavior (pp. 44-62). Toronto: Hogrefe.

Sekaran, U. (2006). Research methods for business: A skill building approach. New York: John Wiley and Sons.

Shamdasani, P.N., \& Balakrishnan, A.A. (2000). Determinant of relationship quality and loyalty in personalized services. Asia Pacific Journal of Management, 17, 399422. https://doi.org/10.1023/A:1015834214570

Smith, J.B., \& Barclay, D.W. (1997). The effects of organizational differences and trust on the effectiveness of selling partner relationships. Journal of Marketing, 61(January), 3-21. https://doi.org/10.2307/1252186

Su, L.J., Hsu, M.K., \& Swanson, S. (2014). The effect of tourist relationship perception on destination loyalty at a world heritage site in China: The mediating role of overall destination satisfaction and trust. Journal of Hospitality and Tourism Research, 20(10), 1-31.

Tomiuk, M.A. (2000). The impact of service providers' emotional displays on service evaluation: Evidence of emotional contagion. $\mathrm{PhD}$ dissertation, Concordia University, Quebec, Canada.

Tung, B., \& Carlson, J. (2013). Modeling a formative measure of relationship quality and its effects: Evidence from Hong Kong retail banking industry. Services Marketing Quarterly, 34, 139-158. https://doi.org/10.1080/15332969.2013.770674

Valdesolo, P., \& Graham, J. (2014). Awe, uncertainty and agency detection. Psychological Science, 25, 170-178. https://doi.org/10.1177/0956797613501884

Wang, E.S.T. (2009). Displayed emotions to patronage intention: Consumer response to contact personnel performance. The Service Industries Journal, 29(3), 317-329. https://doi.org/10.1080/02642060701846747

Wharton, A.S., \& Erickson, R.J. (1993). Managing emotion on the job and at home: Understanding the consequences of multiple emotional roles. Academy of Management Review, 18(3), 457-486. https://doi.org/10.2307/258905 \& https://doi.org/10.5465/AMR.1993.9309035147 
William, L.A. \& DeSteno, D. (2008). Pride and perseverance: The motivational role of pride. Journal of Personality and Social Psychology, 94, 1007-1017. https://doi. org/10.1037/0022-3514.94.6.1007

Wong, Y.H., Hung, H., \& Chow, W-K. (2008). Mediating effect of relationship quality on customer relationship: An empirical study in Hong Kong. Marketing Intelligence and Planning, 25(6), 581-596. https://doi.org/10.1108/02634500710819950

Wyman, O. (2008). The future of private banking: A wealth of opportunity. Retrieved 22 April 2014 from http://www.oliverwyman.com

Zapf, D., Isik, A., Bechtoldt, M., \& Blau, P. (2003). What is typical for call centre jobs? Job characteristic and service interaction in different call centres. European Journal of Work and Organizational Psychology, 12(4), 311-340. https://doi. org/10.1080/13594320344000183

Zeithaml, V.A., Berry, L.L., \& Parasuraman, A. (1996). The behavioral consequences of service quality. Journal of Marketing, 60, 31-46. https://doi.org/10.2307/1251929 